\title{
The urinary excretion of selenium in sheep treated with a vasopressin analogue
}

\author{
Lubomír LENG ${ }^{\text {a*}}$, Klaudia BOLDIŽÁROVÁa ${ }^{\text {Stefan FAIX }}$, \\ Gabriel KovÁčb

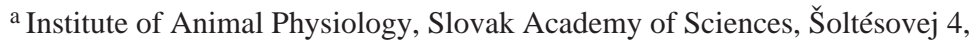 \\ 04001 Košice, Slovak Republic \\ ${ }^{\mathrm{b}}$ University of Veterinary Medicine, Department of Internal Diseases of Ruminants and Swine, \\ Komenského 73, 04181 Košice, Slovak Republic
}

(Received 2 March 2000; accepted 22 May 2000)

\begin{abstract}
The renal excretion of selenium was investigated in ewes with an excretion of hypotonic urine (control group) and in ewes with a formation of highly concentrated urine. Chronic stimulation of the urinary concentrating activity of sheep kidneys was induced by a long-term treatment with 1-desamino-8-D-arginine vasopressin (dDAVP), a synthetic analogue of vasopressin with prolonged effects. Young animals with 22 to $25 \mathrm{~kg}$ b.w. were fed a normal protein diet providing a daily intake of $129.25 \mathrm{~g}$ of crude protein, $12.03 \mathrm{MJ}$ of digestible energy and $0.18 \mathrm{mg}$ of selenium for 3 weeks. The vasopressin treated sheep $(n=11)$ were given subcutaneous injections of $12.5 \mu \mathrm{g}$ of dDAVP in glycerol twice daily for one week before the clearance measurement of renal functions. The control group $(n=11)$ was treated with glycerol only. The administration of dDAVP resulted in a highly significant decrease of the urinary flow rate (from $3.19 \pm 0.50$ in control group to $0.33 \pm 0.03 \mathrm{~mL} \cdot \mathrm{min}^{-1}$ in dDAVP animals, $P<0.001)$ without changes in the glomerular filtration rate $(80.18 \pm 6.36$ in controls vs. $77.86 \pm 6.26 \mathrm{~mL} \cdot \mathrm{min}^{-1}$, NS). No effects on plasma selenium level were observed $\left(0.17 \pm 0.03\right.$ in controls vs. $0.20 \pm 0.03 \mu \mathrm{mol} \cdot \mathrm{L}^{-1}$, NS) but the amounts of selenium excreted were found to be highly significantly reduced (from $0.29 \pm 0.05$ in controls to $0.03 \pm 0.01 \mathrm{nmol} \cdot \mathrm{min}^{-1}, P<0.001$ ) in dDAVP treated sheep. Despite a large reduction in urinary flow rate, the selenium concentration in urine was actually the same in both groups $\left(0.09 \pm 0.01 \mu \mathrm{mol} \cdot \mathrm{L}^{-1}\right)$ resulting in a sharp fall in the renal clearance of selenium $\left(2.20 \pm 0.54\right.$ in controls vs. $\left.0.18 \pm 0.03 \mathrm{~mL} \cdot \mathrm{min}^{-1}, P<0.01\right)$ due to dDAVP. This seems to be a consequence of the large increase in the selenium solvent drag induced by a vasopressin treatment. The results presented suggest that vasopressin may contribute to maintenance of the selenium balance in sheep via its effects on renal function.
\end{abstract}

sheep / kidney / renal function / vasopressin / selenium excretion

* Correspondence and reprints

Tel.: (421) 956332 048; fax: (421) 9567645 35; e-mail: lleng@ saske.sk 
Résumé - Excrétion urinaire de sélénium chez le mouton traité avec un analogue de la vasopressine. L'excrétion rénale du sélénium a été mesurée chez des brebis produisant des urines hypotoniques (groupe témoin) et des urines très concentrées. La stimulation chronique de l'activité rénale de concentration urinaire a été obtenue par traitement à long terme avec de la 1-désamino-8-D-arginine vasopressine (dDAVP), un analogue synthétique de la vasopressine aux effets prolongés. Des jeunes brebis (22 à $25 \mathrm{~kg}$ poids vif) ont été nourries avec un régime normoprotéique (protéine brute $=129,25 \mathrm{~g}$; énergie digestible $=12,03 \mathrm{MJ}$ et sélénium $=0,18 \mathrm{mg}$ par jour) pendant trois semaines. Les brebis traitées $(n=11)$ ont reçu une solution de glycérol contenant $12,5 \mu \mathrm{g}$ de dDAVP par voie sous-cutanée, deux fois par jour pendant une semaine, juste avant les mesures de clairance rénale. Le groupe témoin $(n=11)$ a reçu du glycérol seul. L'administration de dDAVP a induit une réduction très significative de la diurèse (de $3,19 \pm 0,50 \mathrm{chez}$ les témoins à $0,33 \pm 0,03 \mathrm{~mL} \cdot \mathrm{min}^{-1}$, $P<0,001)$ sans modifier le débit de filtration glomérulaire $(80,18 \pm 6,36$ chez les témoins contre $\left.77,86 \pm 6,26 \mathrm{~mL} \cdot \mathrm{min}^{-1}, \mathrm{NS}\right)$. Le niveau plasmatique de sélénium n'a pas été modifié par l'administration de $\operatorname{dDAVP}\left(0,17 \pm 0,03 \mathrm{chez}\right.$ les témoins contre $\left.0,20 \pm 0,03 \mu \mathrm{mol} \cdot \mathrm{L}^{-1}, \mathrm{NS}\right)$, mais la quantité de sélénium éliminée a été très significativement réduite (de $0,29 \pm 0,05$ chez les témoins à $0,03 \pm 0,01 \mathrm{nmol} \cdot \mathrm{min}^{-1}$ chez le groupe traité, $\left.P<0,001\right)$. Malgré la chute de la diurèse, la concentration urinaire de sélénium n'a pas varié sous dDAVP $\left(0,09 \pm 0,01 \mu \mathrm{mol} \cdot \mathrm{L}^{-1}\right.$ chez les deux groupes) et, de ce fait, la clairance rénale du sélénium s'est vue fortement diminuée $(2,20 \pm 0,54$ chez les témoins contre $\left.0,18 \pm 0,03 \mathrm{~mL} \cdot \mathrm{min}^{-1}, P<0,01\right)$. Ceci peut être attribué à une augmentation du phénomène de drainage par le solvant à la suite du traitement avec dDAVP. Ces résultats suggèrent que la vasopressine peut contribuer à la régulation du bilan de sélénium chez le mouton, par le biais de ses effets sur la fonction rénale.

mouton / rein / fonction rénale / vasopressine / excrétion du sélénium

\section{INTRODUCTION}

Selenium (Se) plays an important role in the various vital functions of mammals and therefore it is considered to be the essential trace element. Se is the key structural component of selenoproteins like glutathione peroxidase, iodothyronine deiodinase and many other enzymes. More than 30 other selenoproteins have been identified up to date [11]. Besides the well-known antioxidant activity of Se-enzymes, Se supplementation has been shown to exert positive effects on milk yield, milk somatic cell count, immune response, growth and in the treatment of nutritional muscular dystrophy in ruminants $[2,5,7,9,16]$.

The main excretion routes for Se are the faeces and urine but some small amounts can also be eliminated by the lungs. The amount of selenium excreted in the urine depends on the level of selenium intake, its chemical form, the composition of the diet, the physiological and selenium status of the animals and on the glomerular filtration rate of the kidneys [4, 10, 18]. A considerably larger proportion of the organic forms of selenium was found to be retained in the body, in contrast to inorganic forms which are absorbed rapidly but are equally rapidly excreted in the urine. The total recovery in the urine and faeces of selenate and selenite was $82-95 \%$ of the total dose given to humans whereas only $26 \%$ of selenomethionine was recovered [18].

The use of serum Se concentration to assess nutritional status of cattle with respect to selenium was shown not to be appropriate [8]. Despite variability in renal free water clearance, the urinary selenium concentration appears to be a sensitive indicator of sodium selenite consumption in excess of nutritional requirements in cows [3]. The question arises if one should also consider kidney function when selenium excretion is used as the parameter for selenium status in animals with no additional supplement of Se-intake.

Up to now, the data on renal handling of selenium in ruminants is rather of empiric 
character. Therefore, the aim of this experiment was to obtain basic knowledge on renal clearance and excretion of selenium in sheep with various urinary concentrating activities of kidneys.

\section{MATERIALS AND METHODS}

\subsection{Animals, diet and treatment}

Twenty-two young ewes (Ovis aries) of the Merino breed, weighing between 22 and $25 \mathrm{~kg}$ were housed in individual pens. The animals were fed a normal protein diet for at least 3 weeks before the measurement of kidney functions. The total daily ration for each sheep consisted of $500 \mathrm{~g}$ of hay, $300 \mathrm{~g}$ of barley and $250 \mathrm{~g}$ of wheat bran providing $129.25 \mathrm{~g}$ of crude protein, $12.03 \mathrm{MJ}$ of digestible energy and $0.18 \mathrm{mg}$ of selenium. Animals were fed twice daily at 6.00 AM and 4.00 PM. Water was supplied ad libitum. The animals were divided into two groups. The experimental group of animals $(n=11)$ was treated with 1-desamino-8-Darginine vasopressin (dDAVP, Adiuretin$\mathrm{SD}^{\circledR}$, Ferring-Léčiva a.s., Praha, Czech Republic), a synthetic analogue of vasopressin with prolonged effects. Subcutaneous injections of $12.5 \mu \mathrm{g}$ dDAVP in $125 \mu \mathrm{L}$ of glycerol given twice daily at 6.00 AM and 6.00 PM started one week before the measurements of kidney function. The control group $(n=11)$ received injections of glycerol only for the same period.

\subsection{Renal function measurement}

Renal functions were measured by a standard clearance technique on conscious sheep fixed in cages as recently described [1]. Briefly, the right jugular vein was cannulated with a polyethylene capillary for the infusion of pyrogen-free inulin (Sigma) dissolved in sterile $0.15 \mathrm{~mol} \mathrm{NaCl}$. The priming dose of inulin solution $(1 \mathrm{~g}$ in $50 \mathrm{~mL}$ ) was injected through a jugular cannula and then continuous infusion of inulin $\left(6.6 \mathrm{mg} \cdot \mathrm{mL}^{-1} \cdot \mathrm{min}^{-1}\right)$ was initiated. Blood was sampled from a contralateral jugular vein. Urine was quantitatively collected into calibrated glass cylinders through a Foley catheter (French size 14) placed in the urinary bladder.

The sampling of urine for evaluation of the kidney function started in each sheep $4 \mathrm{~h}$ after the dDAVP or vehiculum administration. The inulin infusion began $90 \mathrm{~min}$ before the first collection period of urine to allow its equilibration in the extracellular space. Each collection period lasted $30 \mathrm{~min}$. Blood samples were collected into heparinised tubes at the mid-point of every urinary collection period. Two collection periods were carried out in every animal. The results from consecutive periods in the same animal were averaged.

\subsection{Samples analysis}

The concentration of inulin was measured in plasma and urine samples by fluorometric method [19]. The osmolality of plasma and urine was determined cryoscopically on a Knauer osmometer. To analyse selenium, the samples of plasma, urine and dietary components were digested with a mixture of $\mathrm{HNO}_{3}$ and $\mathrm{H}_{2} \mathrm{O}_{2}$ in a Millestone microwave oven MLS 1200. Se was measured by graphite furnace atomic absorption spectroscopy on a Perkin Elmer 4100 ZL.

\subsection{Statistical procedure}

Statistical analyses of the differences between the control and dDAVP treated groups were performed by the Student t-test. The results are given as means \pm S.E.M.

\section{RESULTS}

A week-long treatment of sheep with a vasopressin analogue had no effects on the 


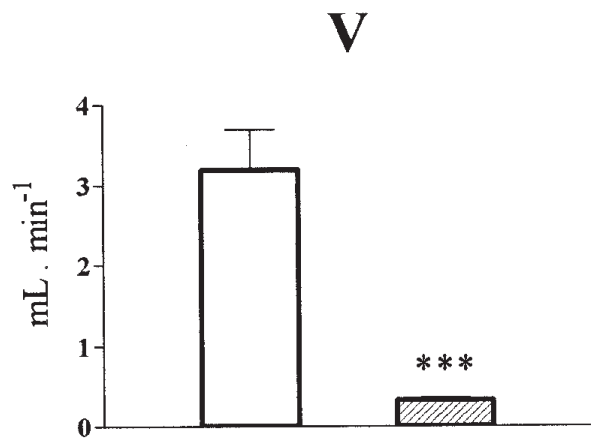

GFR

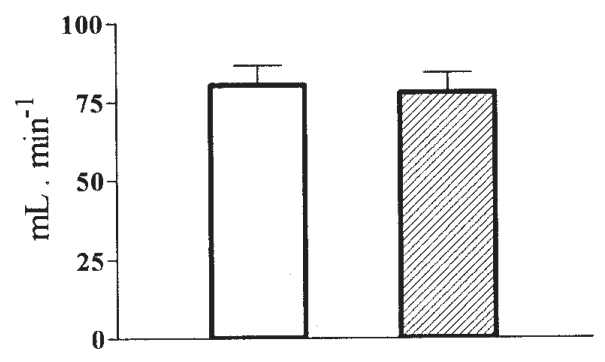

FE $E_{\text {water }}$
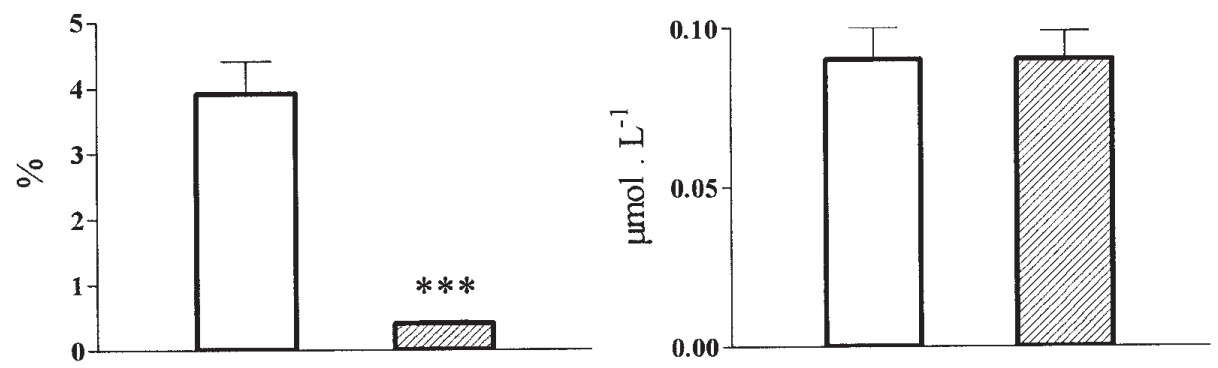

$\mathrm{U}_{\mathrm{Se}} \mathrm{V}$
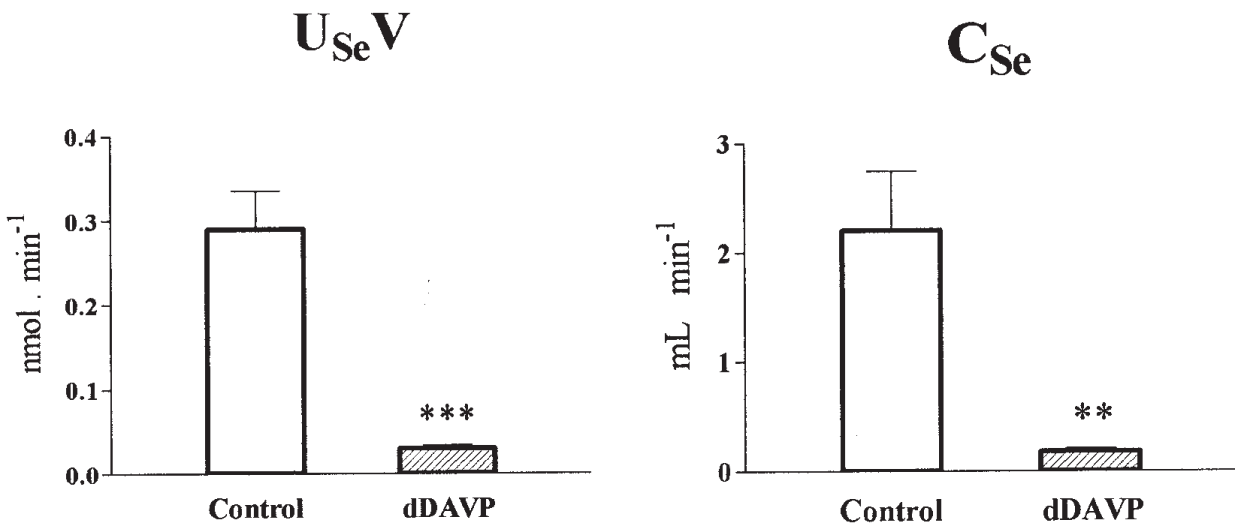

Figure 1. The effects of week-long administration of a vasopressin analogue (dDAVP) on the urine flow rate $(\mathrm{V})$, the glomerular filtration rate $(\mathrm{GFR})$, the fractional excretion of water $\left(\mathrm{FE}_{\mathrm{water}}\right)$, the concentration of Se in urine $\left(\mathrm{U}_{\mathrm{Se}}\right)$, the amount of Se excreted $\left(\mathrm{U}_{\mathrm{Se}} \mathrm{V}\right)$ and on the renal clearance of $\mathrm{Se}\left(\mathrm{C}_{\mathrm{Se}}\right)$. Values are means $\pm \operatorname{SEM}, n=11$ for each group. Significance levels: $* * P<0.01$, *** $P<0.001$. 
plasma selenium level (control $0.17 \pm 0.03$ vs. dDAVP $\left.0.20 \pm 0.03 \mu \mathrm{mol} \cdot \mathrm{L}^{-1}, \mathrm{NS}\right)$.

The long-term formation of highly concentrated urine resulted obviously in a highly significant reduction in urine flow rate (from $3.19 \pm 0.50$ to $0.33 \pm 0.03 \mathrm{~mL} \cdot \mathrm{min}^{-1}$, $P<0.001)$ due to a considerable decrease in fractional water excretion (from $3.92 \pm 0.50$ to $0.41 \pm 0.03 \%, P<0.001)$. No changes in the glomerular filtration rate $(80.18 \pm 6.36$ vs. $77.86 \pm 6.26 \mathrm{~mL} \cdot \mathrm{min}^{-1}$, NS) nor in the selenium concentration of urine $(0.09 \pm 0.01$ vs. $0.09 \pm 0.01 \mu \mathrm{mol} \cdot \mathrm{L}^{-1}$, NS) were observed. Both the amount of selenium excreted (from $0.29 \pm 0.05$ to $0.03 \pm$ $\left.0.01 \mathrm{nmol} \cdot \mathrm{min}^{-1}, P<0.001\right)$ and the renal clearance of selenium (from $2.20 \pm 0.54$ to $\left.0.18 \pm 0.03 \mathrm{~mL} \cdot \mathrm{min}^{-1}, P<0.01\right)$ were ten times reduced in a dDAVP treated group and followed the same pattern as fractional water excretion (Fig. 1).

Data for the osmolality parameters are summarised in Table 1. The osmolality of plasma was slightly but significantly decreased in dDAVP administered animals. Obviously, the osmolality of urine was highly significantly elevated due to vasopressin treatment. Vasopressin had no effect on the clearance of osmotically active substances.

\section{DISCUSSION}

The results of this experiment showed that the selenium concentration in urine of the vasopressin treated sheep did not increase despite of the tenfold reduction in their urinary flow rate. The urinary selenium concentration was not affected by enhanced tubular water reabsorption from the collecting ducts of dDAVP sheep resulting in a sharp fall in the amounts of selenium excreted. Therefore it appeared that the mechanism of solvent drag was responsible for an increased reabsorption of selenium in sheep during a long-term treatment with a vasopressin analogue. The fate of selenium reabsorbed by kidneys of dDAVP sheep could not be determined in our experiment. Though the Se level in plasma of vasopressin treated sheep tended to be higher, the difference was not significant.

Literature data on the urinary selenium excretion in sheep are from balance studies only. We did not measure directly the selenium excretion per $24 \mathrm{~h}$ in our sheep like in balance protocol. We can only calculate from $60 \mathrm{~min}$ of the clearance urinary collection that the amount of selenium excreted per day would be $0.42 \mu \mathrm{mol}$ in our controls and $0.04 \mu \mathrm{mol}$ in vasopressin treated sheep. If we take into account the body weight of sheep used, the calculated daily urinary output of selenium in our controls would be close to values 1.63 or $1.88 \mu \mathrm{mol} \cdot \mathrm{day}^{-1}$ received by Koenig et al. [4] in 3.5 times larger wethers. Krishnamurti et al. [6] reported in twice larger ewes than our sheep the daily selenium excretion $0.44 \mu \mathrm{mol} \cdot \mathrm{day}^{-1}$ for normal and $0.10 \mu \mathrm{mol} \cdot \mathrm{day}^{-1}$ for inadequate Se intake, respectively. It should be stressed out that data calculated from the clearance protocol

Table I. The effects of the week-long administration of vasopressin analogue (dDAVP) on plasma $\left(\mathrm{P}_{\mathrm{osm}}\right)$ and urine $\left(\mathrm{U}_{\mathrm{osm}}\right)$ osmolality and on the osmotic clearance $\left(\mathrm{C}_{\mathrm{osm}}\right)$ in sheep. Values are means \pm SEM.

\begin{tabular}{lccc}
\hline $\begin{array}{c}\text { Control } \\
(n=11)\end{array}$ & $\begin{array}{c}\text { dDAVP } \\
(n=11)\end{array}$ & $\begin{array}{c}\text { Statistical } \\
\text { significance }\end{array}$ \\
\hline $\mathrm{P}_{\text {osm }}\left(\mathrm{mosm} \cdot \mathrm{kg}^{-1} \mathrm{H}_{2} \mathrm{O}\right)$ & $300.07 \pm 0.75$ & $296.55 \pm 0.86$ & $P<0.05$ \\
$\mathrm{U}_{\text {osm }}\left(\mathrm{mosm} \cdot \mathrm{kg}^{-1} \mathrm{H}_{2} \mathrm{O}\right)$ & $254.18 \pm 61.71$ & $1491.36 \pm 67.75$ & $P<0.001$ \\
$\mathrm{C}_{\text {osm }}\left(\mathrm{mL} \cdot \mathrm{min}^{-1}\right)$ & $1.77 \pm 0.10$ & $1.62 \pm 0.08$ & $\mathrm{NS}$ \\
\hline
\end{tabular}


need not fully reflect the real daily urinary Se output.

The important role of the kidneys in homeostatic regulation of selenium has been suggested on the basis of studies on people with different Se intake [14]. Lower renal plasma clearances of selenium, indicating the excretion of smaller proportions of Se presented to the kidneys, were found in people with low plasma Se levels [12]. One of the most important factors influencing the urinary excretion of selenium is its speciation in body fluids. The main metabolites of selenium found in urine are selenomethionine, selenite, selenate, other selenoamino acids, selenocholine and trimethylselenonium ion [18]. Moreover, there are Se-peptides and Se-proteins in plasma. It means that the precise evaluation of the role of the kidney in selenium excretion requires the identification of Se components in glomerular filtrate [13].

To our best knowledge, such data was not available until now. We can only suppose that the filtration of selenoproteins in glomeruli is limited by their molecular weight or diameter. Protein-bound Se can be protected from urinary excretion in such a way. The other Se containing substances should be freely filtered and their excretion depends on tubular reabsorption and/or secretion.

Also the information concerning renal tubular handling of selenium is incomplete. Selenomethionine is absorbed by an active transport system shared with methionine [18]. Under normal conditions, more than $80 \%$ of the filtered Se-amino acids are supposed to be reabsorbed within the first third of the proximal tubule [15]. Due to a lack of the exact information, we can only suppose that the urinary Se-metabolites cross the tubular epithelium by diffusion and/or solvent drag. This seems to be supported by findings that the changes in the proportions of the different Se-forms in plasma of people rapidly alterate renal selenium clearance [12]. In cattle, the differences found in renal excretion of intravenously injected selenite and selenate were rather explained by a more readily incorporation of $\mathrm{SeO}_{3}{ }^{2-}$ into tissues than by some reabsorption in kidneys [17].

The huge increase in the osmolality of urine in the experimental group confirms the efficiency of the injected vasopressin analogue. The slightly but significantly smaller osmolality of plasma in dDAVP sheep was due to a considerably larger reabsorption of water from collecting ducts than in control animals.

In conclusion, data from this experiment show that a vasopressin induced long-term formation of highly concentrated urine in sheep results in a considerable reduction of renal selenium excretion which seems to be a consequence of large Se tubular reabsorption by solvent drag. Vasopressin may contribute to the maintenance of the selenium balance in sheep via its effect on water reabsorption in the collecting ducts. The urinary concentration status should be considered when Se excretion is used as a parameter for the assessment of selenium status in ruminants with no supplementary intake of this element.

\section{ACKNOWLEDGEMENTS}

This study was supported by the Grant Agency for Science VEGA of the Slovak Republic, grant no. 2/7028/20. The authors thank Ferring-Léčivá a.s., Praha, Czech Republic for kindly supplying Adiuretin-SD ${ }^{\circledR}$. We are grateful to Dr. Jesenská and Dr. Hiščáková for excellent technical assistance.

\section{REFERENCES}

[1] Boldižárová K., Faix Š., Leng L., The renal response of sheep fed a high protein diet to treatment with vasopressin analogue, Acta Vet. Brno. 68 (1999) 99-104.

[2] Ceballos M.A., Wittwer F.G., Metabolismo del selenio en rumiantes, Arch. Med. Vet. 28 (1996) 5-18.

[3] Ellis R.G., Herdt H.T., Stowe H.D., Physical, hematologic, biochemical, and immunologic effects of supranutritional supplementation with 
dietary selenium in Holstein cows, Am. J. Vet. Res. 58 (1997) 760-764.

[4] Koenig K.M., Rode L.M., Cohen R.D., Buckley W.T., Effects of diet and chemical form of selenium on selenium metabolism in sheep, J. Anim. Sci. 75 (1997) 817-827.

[5] Kováč G., Sankari S., Glutathione peroxidase activity, selenium concentration in the blood and the masticatory muscle of cattle, Folia Vet. 32 (1988) 78-94

[6] Krishnamurti C.R., Ramberg C.F. Jr., Shariff M.A., Boston R.C., A compartmental model depicting short-term kinetic changes in selenium metabolism in ewes fed hay containing normal or inadequate levels of selenium, J. Nutr. 127 (1997) 95-102.

[7] Lacetera N., Bernabucci U., Ronchi B., Nardone A., The effects of injectable sodium selenite on immune function and milk production in Sardinian sheep receiving adequate dietary selenium, Vet. Res. 30 (1999) 363-370.

[8] Maas J., Galey F.D., Peauroi J.R., Case J.T., Littlefield E.S., Gay C.C., Koller L.D., Crisman R.O., Weber D.W., Warner D.W., Tracy M.L., The correlation between serum selenium and blood selenium in cattle, J. Vet. Diagn. Invest. 4 (1992) 48-52.

[9] Milad K., Kováč G., Review article: Vitamin E and selenium in sheep, Folia Vet. 42 (1998) 87-94.

[10] Oster O., Prellwitz W., The renal excretion of selenium, Biol. Trace Elem. Res. 24 (1990) 119146.
[11] Reilly C., Selenium: A new entrant into the functional food arena, Food Sci. Technol. 9 (1998) 114-118.

[12] Robinson J.R., Robinson M.F., Levander O.A., Thomson C.D., Urinary excretion of selenium by New Zealand and North American human subjects on differing intakes, Am. J. Clin. Nutr. 41 (1985) 1023-1031.

[13] Robinson M.F., Thomson C.D., Jenkinson C.P., Luzhen G., Whanger P.D., Long-term supplementation with selenate and selenomethionine: urinary excretion by New Zealand women, Br. J. Nutr. 77 (1997) 551-563.

[14] Sanz M., Diaz C., Urinary selenium concentration [Review], Clin. Chem. 39 (1993) 2040-2052.

[15] Silbernagl S., Renal transport of amino acids, Klin. Wochenschr. 57 (1979) 1009-1019.

[16] Smith K.L., Hogan J.S., Weiss W.P., Dietary vitamin $\mathrm{E}$ and selenium affect mastitis and milk quality, J. Dairy Sci. 75 (1997) 1659-1665.

[17] Symonds H.W., Mather D.L., Vagg M.J., The excretion of selenium in bile and urine of steers: the influence of form and amount of Se salt, Br. J. Nutr. 46 (1981) 487-493.

[18] Thomson C.D., Selenium speciation in human body fluids, Analyst 123 (1998) 827-831.

[19] Vurek G., Pegram S., Fluorometric method for the determination of nanogram quantities of inulin, Anal. Biochem. 16 (1966) 409-419. 